\title{
IMPLEMENTASI PENDIDIKAN KARAKTER DI PESANTREN KRAPYAK YOGYAKARTA
}

\author{
Miftahuddin \\ Fakultas Ilmu Sosial Universitas Negeri Yogyakarta \\ Email: miftah_uny@yahoo.com
}

\begin{abstract}
Abstrak: Implementasi Pendidikan Karakter di Pesantren Krapyak Yogyakarta. Penelitian ini bertujuan untuk mengetahui pola pengajaran akhlak dalam pembentukan karakter siswa (santri) dan cara penanaman ajaran Islam yang diduga sesuai dengan budaya dan nilai-nilai yang ingin dikembangkan di Indonesia. Penelitian ini merupakan penelitian deskriptif kualitatif. Subjek penelitian adalah Pesantren Krapyak Yogyakarta. Teknik pengumpulan data menggunakan observasi, interviu, dan dokumentasi. Hasil penelitian menunjukkan bahwa pola pengajaran di Pesantren Krapyak ini, baik secara formal maupun non-formal, semua mengarah kepada pembekalan santri atau siswa untuk memiliki akhlak Islami sesuai dengan nilai-nilai budaya yang pada dasarnya ingin dikembangkan di Indonesia. Materi yang terdapat dalam kitab kuning yang digunakan sebagai rujukan diketahui penuh dengan ajaran akhlak yang mulia atau karakter yang baik. Karakter disiplin, kerja keras, kebersamaan, kesederhanaan, kesabaran, toleransi, dan moderat adalah bagian dari ajaran kitab kuning dan tradisi yang telah berkembang di Pesantren Krapyak.
\end{abstract}

Kata kunci: Kitab Kuning, pendidikan karakter, Pesantren Krapyak, nilai-nilai luhur Bangsa Indonesia

\begin{abstract}
The Implementation of Character Education in Pesantren Krapyak, Yogyakarta. This study was aimed at determining the pattern of moral teachings in the character building of the students (santri) and at investigating how the Islamic values which conform Indonesian culture are cultivated among the santri of Pesantren Krapyak. This study is a descriptive qualitative research. The primary data were collected from the santri and the teacher of Pesantren Krapyak in Yogyakarta through observations and interviews. The results show that the pattern of teaching in Pesantren Krapyak, both formal and non-formal, all lead to the debriefing of students to incorporate Islamic values which conform to the cultural values in Indonesia. The material contained in Kitab Kuning, which is used as a reference, is full of noble moral teachings. Similarly, the tradition developed in Pesantren Krapyak equips the students with the characters of discipline, hard work, unity, simplicity, patience, tolerance, and moderate.
\end{abstract}

Keywords: character education, Kitab Kuning, Pesantren Krapyak, Indonesian cultural values

\section{PENDAHULUAN}

Karakter berarti kualitas atau kekuatan mental, akhlak atau budi pekerti individu sebagai kepribadian khusus, yang akan menjadi pendorong. Orang yang berkarakter, berarti dia memiliki kepribadian seperti sifat kejujuran, amanah, dan keteladanan (Hidayatullah, 
2010: 12-14). Tentu saja, proses pendidikan erat kaitannya dengan pembentukan karakter anak didik.

Pendidikan, disebutkan, adalah proses pemanusiaan manusia muda atau pengangkatan manusia muda ke taraf insani. Pendidikan merupakan tuntunan di dalam hidup tumbuhnya anak-anak. Artinya, proses pendidikan akan menuntun segala kekuatan kodrat pada anakanak itu agar mereka sebagai manusia dan sebagai anggota masyarakat dapat mencapai keselamatan dan kebahagiaan yang setinggi-tingginya (Hasbullah, 1999: 4).

Pengkajian pesantren erat kaitannya dengan pendidikan karakter. Tujuan umum pendidikan pesantren diketahui adalah untuk membimbing santri agar menjadi manusia yang berkepribadian Islam. Tujuan khususnya adalah mempersiapkan santri untuk menjadi orang alim dan mendalam ilmu agamanya serta mengamalkannya dalam masyarakat. Dengan demikian, tujuan terpenting pendidikan pesantren adalah membangun moralitas agama santri dengan pengamalannya (Mansur, 2004: 26-27).

Sebagai tempat memahami dan mendalami ajaran Islam serta pembentukan karakter Islami, pesantren mempunyai ciri khas tersendiri. Oleh karena itu, kehidupan di pesantren sering disebut unik, sehingga Abdurrahman Wahid (2007: 1-9) menyebutnya sebagai subkultur. Disebut subkultur dikarenakan pesantren memiliki keunikan sendiri dalam aspek-aspek, seperti cara hidup yang dianut, pandangan hidup dan tata nilai yang diikuti, serta hirarki kekuasaan intern tersendiri yang ditaati sepenuhnya.

Pendidikan pesantren menghasilkan pandangan hidup dan aspirasi yang khas pula. Misalnya, visi untuk mencapai penerimaan di sisi Allah di hari kelak menempati kedudukan terpenting dalam tata nilai di pesantren. Visi semacam ini dalam terminologi pesantren sering dikenal dengan nama keikhlasan. Orientasi ke arah kehidupan alam akherat ini, yang terutama ditekankan pada pengajaran perintah-perintah agama seteliti dan selengkap mungkin, merupakan pokok dasar kehidupan pesantren, sebagaimana dapat ditemukan pada literatur yang digunakan dan diwajibkan di dalamnya.

Sebagai sebuah model pendidikan karakter, masyarakat pesantren ini penting untuk dikaji dan diungkapkan. Bisa jadi, karakter yang muncul dari hasil pendidikan pesantren cocok untuk dijadikan rujukan bagi masyarakat Indonesia pada umumnya. Untukitu, tujuan yang ingin dicapai dalam kajian ini adalah pertama mengetahui pola pengajaran akhlak dan pembentukan karakter siswa (santri) di Pesantren Krapyak. Kedua, mengetahui cara penanaman ajaran Islam di Pesantren Krapyak. Ketiga, menemukan keterkaitan ajaran Islam dengan karakter bangsa Indonesia.

\section{METODE}

Penelitian ini merupakan penelitian deskriptif kualitatif, yang bermaksud untuk menggambarkan, mengungkap, dan menjelaskan implementasi pendidikan karakter di Pondok Pesantren Krapyak Yogyakarta. Sebagaimana dikatakan Nazir (2005: 55) bahwa penelitian deskriptif bertujuan untuk membuat gambaran mengenai situasi atau kejadian. Dalam penelitian deskriptif, kerja peneliti bukan saja memberikan gambaran terhadap fenomena-fenomena, tetapi juga menerangkan hubungan, menguji hipotesis-hipotesis, membuat prediksi, serta mendapatkan makna dan implikasi dari suatu masalah yang ingin dipecahkan. Penelitian ini juga dinamai penelitian 
kualitatif, karena menggunakan dan memahami fenomena yang terjadi di sekitar sekolah (lembaga pendidikan).

Teknik pengumpulan data yang digunakan dalam penelitian ini adalah melalui observasi, interviu, dan dokumentasi. Observasi diarahkan kepada perhatian pada jenis kegiatan dan peristiwa tertentu yang memberikan informasi dan pandangan yang benar-benar berguna (Moleong, 2002: 128). Pengamatan dilakukan dengan cara melihat dan peneliti mengamati sendiri terkait dengan fenomena pesantren dan di Pondok Pesantren Yogyakarta pada khususnya yang dianggap penting, kemudian kejadian itu dicatat sebagaimana terjadi pada keadaan sebenarnya.

Interviu dilakukan dengan mengajukan pertanyaan-pertanyaan terbuka, yang memungkinkan responden memberikan jawaban secara luas. Pertanyaan diarahkan pada pengungkapan kehidupan responden, konsep, persepsi, peranan, kegiatan, dan peristiwaperistiwa yang dialami berkenaan dengan fokus yang diteliti (Sukmadinata, 2009: 112). Dalam penelitian ini interviu dilakukan kepada pengasuh pesantren, guru atau ustadz, para santri.

Sementara itu, dokumentasi digunakan untuk memperoleh data mengenai gambaran keberadaan objek yang diteliti, di samping juga untuk melengkapi data-data yang diperoleh dari hasil pengamatan dan interviu. Dokumen dalam penelitian ini berupa informasi tertulis yang berkenaan dengan pelaksanaan pembelajaran di pesantren, seperti kurikulum dan kitab-kitab atau buku yang dikaji di pesantren.

Untuk mendapatkan data yang dapat dipertanggungjawabkan secara ilmiah, maka data-data yang telah terkumpul terlebih dahulu diperiksa keabsahannya. Teknik pemeriksaan keabsahan data yang digunakan adalah teknik cross check, yaitu teknik penyilangan informasi yang diperoleh dari sumber sehingga pada akhirnya hanya data yang absah saja yang digunakan untuk mencapai hasil penelitian. Teknik cross check ini dilakukan dengan cara mengecek ulang informasi hasil pengamatan dan interviu dengan dokumentasi.

Setelah mendapatkan data yang dapat dipertanggungjawabkan, proses selanjutnya adalah dilakukan analisis. Analisis data menunjuk pada kegiatan mengorganisasikan data ke dalam susunan-susunan tertentu dalam rangka penginterpretasian data. Data ditabulasi sesuai dengan susunan sajian data yang dibutuhkan untuk menjawab masingmasing masalah dan/atau hipotesis penelitian. Hasilnya diinterpretasikan atau disimpulkan, baik untuk masing-masing masalah atau hipotesis penelitian maupun untuk keseluruhan masalah yang diteliti (Faisal, 2001: 34).

Teknik analisis data yang digunakan dalam penelitian ini adalah teknik analisis induktif, yaitu analisis yang bertolak dari data dan ber-muara pada simpulansimpulan umum. Kesimpulan umum itu bisa berupa kategorisasi maupun proposisi (Bungin, 2001: 209).

\section{HASIL DAN PEMBAHASAN}

\section{Kurikulum dan Model Pembelajaran di Pesantren Krapyak}

Buku pegangan atau referensi murid-murid pesantren, yang masih mempertahankan ketradisionalannya, sering disebut dengan kitab kuning. Pengajaran kitab kuning di Pondok Pesantren Krapyak diselenggarakan dalam beberapa model, yaitu sistem klasikal, sorogan, dan bandongan.

Sistem klasikal adalah proses belajar mengajar yang diselenggarakan di kelas-kelas yang dilembagakan dalam 
bentuk sekolah keagamaan (Madrasah Diniah). Pengajaran klasikal di Pondok Pesantren Al-Munawwir ada dalam bentuk Ma'had Aly dan Madrasah Salafiah, sedangkan di Pondok Pesantren Ali Maksum dikenal dengan Madrasah Diniah. Pengajaran kitab kuning dalam bentuk klasikal ini berjenjang dari kelas rendah sampai kelas tinggi, dan kurikulumnya pun disesuai-kan dengan jenjang kelas.

Sorogan adalah bentuk pengajaran kitab kuning yang dilakukan dengan cara guru mengajar santri secara satu per satu dan berhadap-hadapan. Jenis kitab yang diajarkan biasanya disesuaikan dengan keinginan santri, atau bisa juga sesuai dengan anjuran guru. Sistem sorogan ini pada dasarnya untuk membantu santri agar cepat dapat membaca dan memahami kitab kuning, karena dengan sistem semacam ini kesalahan santri dalam membaca kitab kuning langsung dapat diketahui sang guru. Pembelajaran kitab kuning dengan sistem sorogan ini biasanya mengambil waktu yang disesuaikan dengan waktu luang guru, kapan yang bersangkutan bisa mengajar.

Sistem bandongan atau wetonan adalah bentuk pengajaran kitab kuning yang diselenggarakan oleh guru atau kiai yang diikuti santri tanpa melihat jenjang kemampuan tertentu. Kitab yang diajarkan biasanya disesuaikan dengan selera kiai, yang menurutnya dianggap penting untuk diajarkan sebagai pengetahuan tambahan santri. Pengajaran dengan sistem ini memerlukan tempat yang luas, dan biasanya menggambil serambi masjid sebagai kelas. Sistem bandongan ini biasanya diselenggarakan secara melingkar dan duduk langsung di atas lantai.

Kitab-kitab yang diajarkan dapat digolongkan ke dalam 8 kelompok, yaitu tata bahasa Arab yang mencakup nahwu (syntax) dan saraf (morfologi), fiqh, ushul fiqh, hadits, tafsir, tauhid, tasawuf dan etika, dan cabang-cabang lainnya seperti tarikh (sejarah) (Dhofier, 1994).

Pada dasarnya pengajaran kitab-kitab di pesantren baik Al-Munawwir maupun Ali Maksum bertujuan membekali para santri tentang pengetahuan Islam dan cara pengamalan Islam (berkarakter Islami). Apabila dilihat, pada dasarnya berbagai kitab yang diajarkan akan membekali santri tentang pengetahuan Islam lebih dalam. Misalnya, kepada para santri diajarkan cara atau metode memahami AlQur'an dan Hadits sebagai sumber utama Islam. Dalam konteks ini, santri dibekali ilmu untuk dapat menafsirkan Al-Qur'an dan menentukan mana Hadits yang shahih (benar) dan mana yang tidak shahih.

Islam juga mengatur hukum bagaimana seharusnya umatnya berhubungan baik dengan Tuhan dan sesama manusia. Untuk membekali pengetahuan ini, maka para santri Pesantren Krapyak dibekali ilmu fiqih, baik fiqih ibadah maupun muamalah. Perangkat ini dapat dilihat dalam kitab Fathul Qorib, Tadzhib, Fathul Mu'in, Fasholatu: Mabadi Fiqhiyah. Lebih lengkap lagi, santri juga dibekali ilmu cara memutuskan dan menentukan hukum yang tepat. Oleh karena itu, kepada santri diajarkan kitab yang berkaitan dengan metodologi dan metode pengeluaran hukum. Sementara itu, pengajaran kitab di Pesantren Krapyak yang memuat metodologi, misalnya, terdapat dalam Ushul Fiqh dan Qowaidul Fiqhiyah.

Demikian pula, Islam berhubungan erat dengan akhlak. Kitab akhlak yang diajarkan kepada santri Pondok Pesantren Krapyak adalah Ta 'imul Muta`alim. Kitab ini memberi pengetahuan kepada santri cara berperilaku kepada Allah, ilmu, dan guru. Sebaliknya, dalam kitab ini juga diajarkan perilaku guru yang 
baik. Dalam kitab Ta'limul Muta 'alim, alZarnuji (penulis), menawarkan bahwa menjadi guru harus 'alim (profesional), wara' (orang yang dapat menjauhi diri dari perbuatan tercela), tawadlu (tidak sombong dengan keilmuannya), dan iffah (dapat mengekang hawa nafsu). Demikian pula, sebagai murid haruslah sabar dan tabah dalam proses menuntut ilmu, bersungguh-sungguh, terus-menerus dalam belajar, dan mengembangkan diskusi (Miftahuddin, 2006).

Di Pondok Pesantren Krapyak juga diajarkan kitab Tasawuf yang yang mengajarkan kepada santri tata cara bagaimana ibadah atau hubungan baik dengan Allah. Kitab-kitab tasawauf mengajarkan kepada santri cara ibadah yang dapat diterima Allah. Ajaran ikhlas dan pembersihan hati adalah inti pokok dari kitab ini. Misalnya, dalam kitabkitab karangan Imam Ghazali, seperti Ihya Ulumuddin dan Minhajul 'Abiddin, diajarkan syarat-syarat apa saja yang harus dilakukan seseorang agar dapat sampai kepada Allah dan ibadahnya diterima. Untuk itu, ada tingkatan-tingkatan yang harus dilalui jika seseorang ingin sampai kepada Allah, yaitu menjalankan syariat, tarikat, hakikat, dan ma'rifat. (Sunanto, 2005: 217-219).

\section{Tradisi Pesantren dan Pembentukan Karakter Santri}

Amaliah atau tindak-tanduk santri di lingkungan pesantren, baik Pesantren Al-Munawwir maupun Ali Maksum adalah wujud dari pengamalan teori yang diajarkan dalam kitab-kitab kuning. Keikhlasan untuk mendapatkan keridhaan Allah adalah dasar prilaku para santri. Jika di pesantren ada kiai sebagai pengasuh, maka keridhaan seorang kiai atas perilaku santri dianggap hal yang penting.
Dalam konteks ini, penghormatan santri kepada kiai semata-mata karena keilmuan yang dimiliki seorang kiai. Kiai diyakini sebagai ulama (orang yang tahu atau 'alim tentang Islam dengan segala isinya), karena mereka adalah pewaris para Nabi. Oleh karena itu, perilaku santri harus selalu merujuk kepada keridhaan kiai, yang semua itu semata-mata demi mencari ridha Allah. Banyak hal yang dapat dicontohkan dari karakter santri Pondok Pesantren Al-Munawir maupun Ali Maksum, seperti disiplin, kerja keras, kebersamaan, kesederhanaan, kesabaran, toleransi, dan moderat.

Disiplin. Sifat disiplin tercermin pada santri, bahwa mereka harus mengerjakan shalat wajib tepat pada waktunya. Setiap masuk waktu shalat lima waktu, maka diadakan panggilan adzan yang mendorong santri harus segera pergi ke masjid untuk mengadakan shalat berjamaah. Semua pekerjaan dan aktivias harus ditinggalkan untuk menunaikan shalat. Untuk membiasakan hal ini, misalnya, dibentuklah pengurus pesantren, yang salah satu tugasnya adalah membangunkan santri dari tidur untuk melakukan shalat berjamaah, terutama pada waktu pagi hari.

Kerja Keras. Sifat kerja keras dapat dijumpai terutama dalam aktifitas belajar para santri. Mereka harus rajin belajar untuk menguasai materi-materi yang terdapat dalam kitab sekalipun harus tidur sampai larut malam dan bangun pagi. Yang perlu diketahui, bahwa kebanyakan santri Pesantren Krapyak disamping mereka sebagai santri yang sedang mengkaji ilmuilmu agama Islam, mereka juga sedang menempuh pendidikan formal, baik di tingkat SMP, SMA, atau perguruan tinggi. Oleh karena itu, mereka harus bekerja keras jika ingin berhasil dalam studinya. 
Selain itu, karakter kerja keras ini juga ditunjukan oleh para santri yang sedang menghafalkan materi-materi tertentu, seperti nadhoman (bait) kitab-kitab nahwa (tata bahasa Arab) dan bahkan menghafal Al-Quran.

Kebersamaan. Kebersamaan ini adalah wujud dari ajaran Islam yang salah satunya tercermin dalam shalat berjamaah. Bentuk nyata dari kebersamaan biasanya dalam setiap pekerjaan yang menyangkut hajat pesantren dikerjakan secara bersama-sama oleh para santri. Misalnya, untuk menjaga kebersihan lingkungan, maka pekerjaan ini dilakukan secara bersama-sama. Demikian pula, ketika pesantren mengadakan acara penting, khaul (peringatan tahunan meninggalnya seorang kiai), maka dibentuklah kepanitiaan yang terdiri dari berbagai koordinator untuk menjalankan tugas masing-masing.

Kesederhanaan. Kesederhanaan ini tercermin dalam penerimaan para santri dengan kondisi tempat tinggal yang seadanya yang berbeda sama sekali dalam hal fasilitas ketika mereka tinggal di rumah atau kos pada umumnya. Misalnya, satu kamar di asrama pesantren yang berukuran kurang lebih $3 \mathrm{~m}$ x $3 \mathrm{~m}$ dapat ditempati oleh tiga sampai lima santri. Fasilitas yang ada di kamar pun sangat sederhana, yang jarang ditemui kasur sebagai alas tidur. Bahkan, tempat tidur mereka bisa di mana saja, bisa di kamar asrama, kelas-kelas, ataupun serambi masjid. Demikian pula, kebanyakan santri dalam hal berpakaian, pola makan, dan gaya hidup selalu menampakkan kesederhanaan sekalipun mereka dari keluarga orang kaya.

Kesabaran. Dalam keseharian, santri Pesantren Krapyak, baik langsung ataupun tidak langsung, mendapatkan ajaran kesabaran. Kitab-kitab yang dikaji, banyak mengajarkan tentang kesabaran. Kitab Al-Hikam dan Awarif al-Ma'arif li Abd al-Qohir, yang digunakan sebagai referensi, mengajarkan bahwa kesabaran diperoleh melalui ibadah. Demikian pula, dalam praktik keseharian di lingkungan pesantren, santri harus membiasakan kesabaran dalam segala tindakan. Misalnya, tradisi mengantri dalam memperoleh jatah makan, mandi, dan buang air besar adalah pembelajaran kesabaran yang harus diterima. Kesabaran santri ini juga tercermin ketika mereka menjalankan shalat wajib tepat pada waktunya, dan sabar beradaptasi dengan teman satu kamar. Kondisi semacam ini mengajarkan kesabaran bagi para santri dan menuntut santri harus kuat untuk menjalankannya. Tentu saja, tanpa kesabaran mereka akan gagal menjadi santri.

Toleransi dan Moderat. Umumnya, bagi santri pesantren yang masih memegangi tradisi salaf (tradisional), seperti Pesantren Krapyak, akidah Ahlussunah wal Jamaah adalah menjadi pegangan mereka. Praktiknya, dalam pesantren ini diajarkan kitab Hujjah Ahlus Sunnah wal Jama`ah. Pengajaran kitab ini, misalnya, dapat dilihat dalam kurikulum Madrasah Salafiah 1 Pondok Pesantren Al-Munawwir. Akidah inilah yang pada kenyataannya dapat membentuk santri berkarakter toleran atau moderat.

Ajaran Ahlussunah wal Jamaah itu sendiri dapat disebut paham yang moderat. Perkataan Ahlusunnah waljama'ah dapat diartikan sebagai "para pengikut tradisi Nabi Muhammad dan ijma (kesepakatan) ulama" (Zamakhsyari Dhofier, 1994: 148). Sementara itu, watak moderat (tawassuth) merupakan ciri Ahlussunah waljamaah yang paling menonjol, disamping juga i' tidal (bersikap adil), tawazun (bersikap seimbang), dan tasamuh (bersikap toleran), sehingga 
ia menolak segala bentuk tindakan dan pemikiran yag ekstrim (tatharruf) yang dapat melahirkan penyimpangan dan penyelewengan dari ajaran Islam. Dalam pemikiran keagamaan, juga dikembangkan keseimbangan (jalan tengah) antara penggunaan wahyu (naqliyah) dan rasio ('aqliyah) sehingga dimungkinkan dapat terjadi akomodatif terhadap perubahanperubahan di masyarakat sepanjang tidak melawan doktrin-doktrin yang dogmatis (Dhofier, 1994: 65).

\section{SIMPULAN}

Dari hasil kajian tentang pendidikan karakter di Pesantren Krapyak dapat disimpulkan, bahwa pada dasarnya pembelajaran yang dilaksanakan di pesantren tersebut bertujuan membekali santri berakhlak mulai. Karakter anak didik yang dibangun melalui proses pendidikan di Pesantren Krapyak adalah karakter yang sesuai dengan budaya dan nilai-nilai yang ingin dikembangkan di Indonesia. Dengan kata lain, ber-Islam yang ingin dibangun di Pesantren Krapyak adalah Islam yang sesuai dengan konteks Indonesia. Dengan bekal pemberian karakter disiplin, kerja keras, kebersamaan, kesederhanaan, kesabaran, toleransi, dan moderat kepada santri Pesantren Krapyak, maka sulit untuk menemukan santri yang berIslam secara fundamental dan radikal. Oleh karena itu, tidak cocok, misalnya, untuk mengalamatkan kepada Pesantren Krapyak sebagai tempat penggemblengan calon-calon "teroris".

\section{DAFTAR PUSTAKA}

Wahid, A. 2007. Menggerakkan Tradisi: Esai-esai Pesantren. Yogyakarta: LkiS.

Bungin, B. 2001. Metode Penelitian Kualitatif: Aktualisasi Metodologis ke Arah Varian Kontemporer. Jakarta: Raja Grafindo Persada.

Dhofier, Z. 1994. Tradisi Pesantren: Studi tentang Pandangan Hidup Kyai. Jakarta: LP3ES.

Faisal, S. 2001. Format-format Penelitian Sosial. Jakarta: Raja Grafindo Persada.

Hasbullah. 1999. Dasar-dasar Ilmu Pendidikan. Jakarta: Raja Grafindo.

Hidayatullah, F. 2010. Pendidikan Karakter: Membangun Peradaban Bangsa, Surakarta: UNS Press.

Mansur. 2004. Moralitas Pesantren: Meneguk Kearifan dari Telaga Kehidupan. Yogyakarta: Safiria Insania Press.

Miftahuddin. 2006. "Konsep Profil Guru dan Siswa (Mengenal Pemikiran AlZarnuji dalam Ta'lim Al-Muta'lim dan Relevansinya)". Cakrawala, Juni 2006, Th. XXV, No. 2.

Moleong, L.J. 2002. Metodologi Penelitian Kualitatif. Bandung: Rosdakarya.

Nazir, M. 2005. Metode Penelitian.Bogor: Ghalia Indonesia.

Sukmadinata, N.S. 2005. Landasan Psikologi Proses Pendidikan. Bandung: Rosdakarya.

Sunanto, M. 2005. Sejarah Peradaban Islam Indonesia. Jakarta: Rajawali Pers. 